2012

\title{
Oxidative Effects of Nanosecond Pulsed Electric Field Exposure in Cells and Cell-Free Media
}

\author{
Olga N. Pakhomova \\ Old Dominion University, opakhomo@odu.edu
}

Vera A. Khorokhorina

Old Dominion University

Angela M. Bowman

Old Dominion University

Raminta Rodaitė-Riševičienè

Gintautas Saulis

See next page for additional authors

Follow this and additional works at: https://digitalcommons.odu.edu/bioelectrics_pubs

Part of the Biochemistry Commons, Biomedical Commons, Cell Biology Commons, and the Molecular Biology Commons

\section{Repository Citation}

Pakhomova, Olga N.; Khorokhorina, Vera A.; Bowman, Angela M.; Rodaitė-Riševičienė, Raminta; Saulis, Gintautas; Xiao, Shu; and Pakhomov, Andrei G., "Oxidative Effects of Nanosecond Pulsed Electric Field Exposure in Cells and Cell-Free Media" (2012).

Bioelectrics Publications. 204.

https://digitalcommons.odu.edu/bioelectrics_pubs/204

\section{Original Publication Citation}

Pakhomova, O. N., Khorokhorina, V. A., Bowman, A. M., Rodaite-Riseviciene, R., Saulis, G., Xiao, S., \& Pakhomov, A. G. (2012).

Oxidative effects of nanosecond pulsed electric field exposure in cells and cell-free media. Archives of Biochemistry and Biophysics, 527(1), 55-64. doi:10.1016/j.abb.2012.08.004 
Authors

Olga N. Pakhomova, Vera A. Khorokhorina, Angela M. Bowman, Raminta Rodaitè-Riševičienè, Gintautas Saulis, Shu Xiao, and Andrei G. Pakhomov 


\title{
Oxidative effects of nanosecond pulsed electric field exposure in cells and cell-free media
}

\author{
Olga N. Pakhomova ${ }^{a}$, Vera A. Khorokhorina ${ }^{a}$, Angela M. Bowman ${ }^{a}$, Raminta Rodaitè- \\ Riševičiené $^{\mathrm{b}}$, Gintautas Saulis ${ }^{\mathrm{b}}$, Shu Xiao ${ }^{\mathrm{a}, \mathrm{c}}$, and Andrei G. Pakhomov ${ }^{\mathrm{a},{ }^{*}}$ \\ aFrank Reidy Research Center for Bioelectrics, Old Dominion University, Norfolk, VA \\ bDepartment of Natural Sciences, Vytautas Magnus University, Kaunas, Lithuania \\ 'Dept. of Electrical and Computer Engineering, Old Dominion University, Norfolk, VA, USA
}

\begin{abstract}
Nanosecond pulsed electric field (nsPEF) is a novel modality for permeabilization of membranous structures and intracellular delivery of xenobiotics. We hypothesized that oxidative effects of nsPEF could be a separate primary mechanism responsible for bioeffects. ROS production in cultured cells and media exposed to $300-\mathrm{ns}$ PEF $(1-13 \mathrm{kV} / \mathrm{cm})$ was assessed by oxidation of 2', $7^{\prime}$-dichlorodihydrofluoresein $\left(\mathrm{H}_{2} \mathrm{DCF}\right)$, dihidroethidium (DHE), or Amplex Red. When a suspension of $\mathrm{H}_{2}$ DCF-loaded cells was subjected to nsPEF, the yield of fluorescent $2^{\prime}, 7^{\prime}$ dichlorofluorescein (DCF) increased proportionally to the pulse number and cell density. DCF emission increased with time after exposure in nsPEF-sensitive Jurkat cells, but remained stable in nsPEF-resistant U937 cells. In cell-free media, nsPEF facilitated the conversion of $\mathrm{H}_{2} \mathrm{DCF}$ into DCF. This effect was not related to heating and was reduced by catalase, but not by mannitol or superoxide dismutase. Formation of $\mathrm{H}_{2} \mathrm{O}_{2}$ in nsPEF-treated media was confirmed by increased oxidation of Amplex Red. ROS increase within individual cells exposed to nsPEF was visualized by oxidation of DHE. We conclude that nsPEF can generate both extracellular (electrochemical) and intracellular ROS, including $\mathrm{H}_{2} \mathrm{O}_{2}$ and possibly other species. Therefore, bioeffects of nsPEF are not limited to electropermeabilization; concurrent ROS formation may lead to cell stimulation and/or oxidative cell damage.
\end{abstract}

\section{Keywords}

nanosecond pulses; electroporation; cell death; pulsed electric field; reactive oxygen species; membrane permeabilization

\section{Introduction}

High-intensity electric pulses of nanosecond duration, also frequently referred to as nanosecond pulsed electric field (nsPEF), have been introduced recently $[1,2]$ as a new agent with potential capability of penetrating plasma membrane and permeabilizing the internal cell structures. Recent studies using widely varied techniques established

\footnotetext{
(c) 2012 Elsevier Inc. All rights reserved.

*Corresponding author: Andrei G. Pakhomov, 4211 Monarch Way, Suite 320, Norfolk, VA 23508, 757-683-8002, 757-314-2397 (fax), apakhomo@odu.edu, 2andrei@pakhomov.net.

Publisher's Disclaimer: This is a PDF file of an unedited manuscript that has been accepted for publication. As a service to our customers we are providing this early version of the manuscript. The manuscript will undergo copyediting, typesetting, and review of the resulting proof before it is published in its final citable form. Please note that during the production process errors may be discovered which could affect the content, and all legal disclaimers that apply to the journal pertain.
} 
permeabilization of the mitochondrial membrane [3], endoplasmic reticulum [4], and plasma membrane [5-10] by nsPEF; other studies evaluated pore size, lifetime, ionic permeability, and consequences for cell function [5, 8-13]. Membrane permeabilization by nsPEF disrupted ion and water balance across the membrane, leading to isoosmotic volume changes and various types of blebbing $[5,8,10]$. NsPEF-induced uptake of extracellular $\mathrm{Ca}^{2+}$ and its release from intracellular depot could trigger a wide spectrum of $\mathrm{Ca}^{2+}$-dependent biochemical cascades [4, 14-16]. Cell damage by nsPEF could cause necrotic or apoptotic cell death [17-20], and the method of nanoelectroablation by nsPEF has shown promise in cancer therapy [21-25].

Although membrane permeabilization is a well-established principal mechanism of nsPEF bioeffects, it is not necessarily the only mechanism. Some complex effects of nsPEF, including inhibition of voltage-gated $\mathrm{Na}^{+}$and $\mathrm{Ca}^{2+}$ transmembrane currents [26] and the phenomenon of electrosensitization [27] cannot be simply explained by formation of membrane pores. With the peak electric field of up to hundreds of kilovolts per centimeter and energy absorption rates on the order of gigawatts per gram, other hypothetical mechanisms of nsPEF effects are cell electrodeformation [28, 29], mechanical stress due to thermoelastic expansion [30, 31], conformational changes in molecular structure [32, 33], and electrolysis and electrodissociation of molecules, possibly including ROS formation [18, 34].

Specifically, several independent lines of evidence suggested oxidative damage in nsPEFtreated cells. Similar to the effect of sparsely-ionizing radiations, the cytotoxic effect of nsPEF was readily modified by the presence of oxygen, and exposure of cells under hypoxic conditions increased the survival about twofold [34]. Other similarities with ionizing radiations were the dependence of cell survival on the absorbed dose and the typical shape of the survival curve (a shoulder followed by an exponential decline) [34, 35].

Cytophysiological manifestations of a chemically-induced oxidative stress [36, 37] were amazingly similar to cellular effects of nsPEF-induced damage [5,6]. The current-voltage (I-V) characteristics and blocker sensitivity of nonselective cation channels (NSCC) stimulated by a free-radical donor calphostin C [37] were indistinguishable from properties of nanoelectropores, thereby raising a question if these (yet unidentified) NSCC and nanoelectropores might actually be the same entity $[5,8]$. Finally, findings of DNA damage following nsPEF exposure [38], stimulation of ROS production following traditional electroporation with long (0.1-15 ms) electric pulses [39-41], and demonstration of the production of ROS during electrolysis [42] provide further support to the feasibility of looking at ROS formation as a potential mechanism of nsPEF bioeffects.

In this study, we demonstrate that nsPEF exposures can cause oxidation in cell suspensions, in cell-free media, and in individual cells.. NsPEF-induced oxidation is a complex process that involves both electrochemical and biological pathways. The impact of nsPEF-generated oxidants $\left(\mathrm{H}_{2} \mathrm{O}_{2}\right)$ on cell survival and physiology was only briefly addressed in this study and will be reported separately.

\section{Methods}

\section{Cell lines and propagation}

All cell lines were obtained from ATCC (Manassas, VA) and propagated at $37^{\circ} \mathrm{C}$ with $5 \%$ $\mathrm{CO}_{2}$ in air. Suspension cells, Jurkat clone E6-1 (human T-lymphocytes) and U-937 (human monocytes) were grown in RPMI-1640 medium supplemented with $10 \%$ fetal bovine serum and $2 \mathrm{mM}$ L-glutamine. Anchor-dependent cells (CHO-K1, Chinese hamster ovary) were propagated in Ham's F12K medium supplemented with 10\% FBS. The media also contained 100 I.U./ml penicillin and $0.1 \mu \mathrm{g} / \mathrm{ml}$ streptomycin. The media and its components were 
purchased from Mediatech Cellgro (Herdon, VA) except for serum (Atlanta Biologicals, Norcross, GA).

Although we used several cell lines, this study was not focused on comparison of cell linespecific characteristics of nsPEF effect. Instead, we intended to demonstrate that nsPEF effects are not unique for just a single, randomly chosen cell line but can be observed in diverse cell lines, albeit with quantitative differences.

\section{Fluorescent dyes, buffers, and chemicals}

Fluorescent dyes dichlorodihydrofluorescein diacetate ( $\mathrm{H}_{2}$ DCFDA), carboxy- $\mathrm{H}_{2}$ DCFDA, N-Acetyl-3,7-dihydroxyphenoxazine (Amplex Red), and dihidroethidium (DHE) were purchased from Invitrogen (Eugene, OR). Other chemicals, including horseradish peroxidase (HRP), tert-butyl hydroperoxide (TBHP), superoxide dismutase from bovine erythrocytes (SOD), and catalase (CAT) were obtained from Sigma-Aldrich (St. Louis, MO).

Chemicals and dyes were diluted in RPMI medium without phenol red or serum, or in phosphate-buffered saline (PBS). In some experiments, we also used a physiological solution (PS) composed of (in mM): $136 \mathrm{NaCl}, 5 \mathrm{KCl}, 2 \mathrm{MgCl}_{2}, 2 \mathrm{CaCl}_{2}, 10 \mathrm{HEPES}$, and 10 glucose (pH 7.4) [5, 9, 27].

\section{Oxidative response in cell suspensions}

$\mathrm{H}_{2}$ DCFDA dye is perhaps the most popular selection for non-specific ROS detection and as an oxidative burst indicator [43-46]. The nonfluorescent $\mathrm{H}_{2}$ DCFDA crosses the cell membrane and, under the action of intracellular esterases, is deacetylated into $2^{\prime} 7^{\prime}$ dichlorodihydrofluorescein $\left(\mathrm{H}_{2} \mathrm{DCF}\right)$. This substance is also non-fluorescent, but has relatively low ability to escape from the cell through the plasma membrane. Oxidation of $\mathrm{H}_{2}$ DCF produces highly fluorescent $2^{\prime}, 7^{\prime}$-dichlorofluorescein (DCF).

$\mathrm{H}_{2}$ DCF is highly sensitive to a broad spectrum of ROS, but, depending on the environmental conditions, can also undergo fast self-oxidation and photooxidation, which must be carefully taken into account. The state of knowledge about this dye, its utility and caveats for ROS detection have been reviewed recently [43].

$\mathrm{H}_{2}$ DCFDA was stored at $-20^{\circ} \mathrm{C}$ as $10-\mathrm{mM}$ aliquots in anhydrous DMSO. For dye loading, cells were collected by centrifugation and resuspended at $1-1.4 \times 10^{6}$ cells $/ \mathrm{ml}$ in RPMI without FBS. Following a 30-min incubation at $37{ }^{\circ} \mathrm{C}$ with $20-50 \mu \mathrm{M}$ of the dye, cells were separated by centrifugation and resuspended in a fresh RPMI medium without phenol red and without FBS. The final cell density was adjusted to $0.6-1.2 \times 10^{6}$ cells $/ \mathrm{ml}$ unless stated otherwise. The cell suspension was dispensed in 1- or 2-mm gap electroporation cuvettes (BioSmith Biotech, San Diego, CA) and subjected to nsPEF exposure or sham exposure, or was used for parallel control. Upon completion of all scheduled exposures, the samples were dispensed in triplicates into a 96-well black-wall plate and read with a Synergy 2 microplate reader (BioTEK, Winooski, VT), with ex./em. settings at 485/528 nm. Depending on the specific protocol, the readings could be performed repeatedly at different time intervals after the exposure. Matched parallel control samples accompanied each exposed sample and were treated in precisely the same manner, excluding only the exposure procedure itself.

As a positive control for ROS production, dye-loaded cells were incubated at $37^{\circ} \mathrm{C}$ with 200 $\mu \mathrm{M}$ TBHP. The incubation started before the first nsPEF exposure, and the sample was read together with all other samples. 
The dye and dye-loaded cell samples were at all times protected from light. Overhead illumination in the experimental lab was turned off for the duration of experiments.

\section{Oxidative response in cell-free media}

As a first step, $\mathrm{H}_{2}$ DCFDA was converted into $\mathrm{H}_{2}$ DCF by alkaline deacetylation as recommended by the supplier. The 10-mM stock of $\mathrm{H}_{2}$ DCFDA was mixed with an equal volume of methanol and 1/2 volume of $2 \mathrm{M} \mathrm{KOH}$. Following 1-hr incubation, $\mathrm{pH}$ was adjusted to 7.0 using $1 \mathrm{M} \mathrm{HCl}$, and the mixture was diluted with a test medium (either RPMI without phenol red and FBS, or PS).

The final concentration of $\mathrm{H}_{2} \mathrm{DCF}$ in the medium was 20 or $70 \mu \mathrm{M}$. In some series of experiments, ROS scavengers were added to the medium prior to nsPEF exposure: mannitol $(10 \mathrm{mM})$, SOD $(50 \mu \mathrm{g} / \mathrm{ml})$, CAT $(0.5 \mathrm{mg} / \mathrm{ml}$, which is approx. $1,000-2,500$ units $/ \mathrm{ml})$, or a cocktail of the latter two enzymes.

Experiments began immediately once all the solutions were prepared. The samples were protected from light at all times. Once an exposure regimen was chosen, the test solution was aliquoted in two identical electroporation cuvettes; one of the cuvettes was exposed to nsPEF (or sham exposed, i.e., placed in the exposure set-up for a certain time, but no pulses were triggered) and the other one served as a parallel control. Immediately after the completion of exposure, the exposed and control samples were dispensed in triplicates into a 96-well plate and read with the plate reader. The interval between exposure and reading was kept to the minimum (about $1 \mathrm{~min}$ ) unless stated otherwise. After reading, the samples were discarded, and the next experiment started using a different exposure regimen and fresh aliquots of the $\mathrm{H}_{2} \mathrm{DCF}$ solution.

We noticed that the self-oxidation of $\mathrm{H}_{2} \mathrm{DCF}$ was facilitated when the sample stayed in the electroporation cuvette. Although the reasons for such behavior have not been studied (either interaction with plastic or with aluminum walls of the cuvette), care was taken to keep the time in the cuvette equal for the exposed and parallel control samples.

\section{Detection of $\mathrm{H}_{2} \mathrm{O}_{2}$ in cell-free media using Amplex Red reagent}

In contrast to $\mathrm{H}_{2} \mathrm{DCF}$, Amplex Red is specifically sensitive to $\mathrm{H}_{2} \mathrm{O}_{2}$. Oxidation of Amplex Red by $\mathrm{H}_{2} \mathrm{O}_{2}$ in the presence of HRP produces highly fluorescent resorufin, ex./ $\mathrm{em} .=563 / 587 \mathrm{~nm}$ [46]. The yield of resorufin was measured with a plate reader both by fluorescence and by absorbance at $560 \mathrm{~nm}$; the results were essentially identical.

Amplex Red was stored frozen at $-20^{\circ} \mathrm{C}$ as a $20 \mathrm{mM}$ DMSO stock. HRP $(250-300 \mathrm{U} / \mathrm{mg})$ was dissolved in water at $3 \mathrm{mg} / \mathrm{ml}$ and stored at $-80^{\circ} \mathrm{C}$. Working solution contained $100 \mu \mathrm{M}$ Amplex Red and 0.2 U/ml HPR in Dulbecco's PBS.

For nsPEF exposure and parallel control, $410-\mu 1$ aliquots of the working solution were dispensed in two identical electroporation cuvettes with 2-mm gap between the electrodes. Immediately after the exposure, the samples were dispensed in triplicate into a 96-well plate $(100 \mu \mathrm{l} /$ well $)$ and measured. After reading, the samples were discarded, and the next experiment started using a different exposure regimen and fresh aliquots of the working solution.

\section{NsPEF exposure of cell suspensions and cell-free media}

Exposure procedures for electroporation cuvettes were the same as described earlier [17, 27]. Sample volumes in 1- and 2-mm gap electroporation cuvettes were 0.14 and $0.42 \mathrm{ml}$, respectively. Unipolar 300-ns pulses were produced by an AVTECH AVOZ-D2-B-ODA 
generator (AVTECH Electrosystems, Ottawa, Ontario, Canada). This generator was triggered externally from a model S8800 stimulator (Grass Instruments Co., Quincy, MA). The pulse amplitude and shape (trapezoidal, with rise and fall times (20\%-80\%) of <100 ns) were monitored using a Tektronix TDS 3052B oscilloscope (Tektronix, Beaverton, OR). Pulses were delivered to the electroporation cuvette using a 50- to 10-Ohm transition module (AVOZ-D2-T, AVTECH Electrosystems) modified into a cuvette holder. The Efield values were obtained by dividing the mean pulse voltage (as measured by the oscilloscope) by the width of the gap in the electroporation cuvette. Parallel control samples were just placed on the table in the vicinity of the exposed sample.

In isolated experiments, the temperature of the sample during and after EP exposure was monitored using a fiber optic ReFlex-4 thermometer (Nortech Fibronic, Quebec City, Quebec, Canada) connected to a computer via a Digidata 1322A interface (MDS, Foster City, CA). As shown below, heating was less than $1{ }^{\circ} \mathrm{C}$ for any of nsPEF treatments that were employed to measure oxidation in cells and media samples.

\section{Measurements of cell survival}

The fraction of live cells in the population was determined by either a standard trypan blue exclusion techique [17, 47], or by a fluorescent dye exclusion/quenching method [27]. For the latter method, $20 \mu 1$ of the cell suspension were mixed with an equal volume of staining solution $(100 \mu \mathrm{g} / \mathrm{ml}$ of propidium iodide and $0.5 \mu \mathrm{g} / \mathrm{ml}$ of acridine orange in PBS). The sample was immediately loaded into a counting chamber of an automated cell counter Cellometer Vision (Nexcelom Bioscience LLC, Lawrence, MA).

Both dyes markedly increase fluorescence upon binding to cell DNA. While acridine orange readily penetrates the intact cell membrane, propidium does not. Live cells were distinguished by bright fluorescence of acridine orange (ex/em 475/535 nm). In cells with damaged membrane (presumably dead), the emission of acridine orange was quenched by propidium.

\section{Confocal microscopy}

For time lapse live cell imaging, cells were grown on glass cover slips pre-treated with polyL-lysine to improve cell adhesion. Cells on the cover slips were loaded with $\mathrm{H}_{2}$ DCFDA or carboxy- $\mathrm{H}_{2}$ DCFDA, similarly to what was described above for suspension cells. Carboxy$\mathrm{H}_{2}$ DCFDA has similar properties as $\mathrm{H}_{2}$ DCFDA, but is better retained by cells after its cleavage by intracellular esterases.

A cover slip with cells was transferred into a glass-bottomed chamber (Warner Instruments, Hamden, CT) filled with PS. The chamber was mounted on an Olympus IX81 inverted microscope equipped with an FV 1000 confocal laser scanning system (Olympus America, Center Valley, PA). Differential interference contrast (DIC) and fluorescent images of cells were collected with a $40 \mathrm{x}$ dry objective $(0.95 \mathrm{NA})$ every $5 \mathrm{sec}$, starting prior to nsPEF exposure and continuing during and after it. Control cells were sham-exposed (see Results and Discussion for detail). In order to minimize photooxidation of the dye, the excitation laser $(488 \mathrm{~nm})$ was tuned to the minimum intensity $(0.1 \%)$ and the scanning time was set to the minimum $(2 \mu \mathrm{s} / \mathrm{pixel})$.

In a separate series of experiments, we used anchor-dependent $\mathrm{CHO}$ cells which (in contrast to U937 and Jurkat) adhered firmly to glass coverslips. The cells were not loaded with any dye; instead, PS in the glass-bottomed chamber contained $30 \mu \mathrm{M}$ of DHE, which is nonfluorescent and can freely travel across the cell membrane [46]. Oxidation of DHE forms ethidium, which binds to DNA becoming highly fluorescent (ex/em 520/610 nm). DHE is thought to be primarily sensitive to the superoxide radical, although cytochrome $\mathrm{C}, \mathrm{H}_{2} \mathrm{O}_{2}$ 
and some other compounds may contribute to its oxidation [46]. Because of its binding to DNA, ethidium is retained even in electropermeabilized cells, which makes this dye indispensable for experiments with nsPEF.

These experiments were specifically aimed at the detection of intracellular oxidation of the dye. In order to preclude the impact of any extracellularly-generated electrochemical species, they were washed away by the fast flow of PS through the bath. The flow ( $4 \mathrm{ml} /$ min) was turned on automatically for $10 \mathrm{~s}$, starting precisely $1 \mathrm{~s}$ prior to nsPEF exposure (the longest exposure was $8 \mathrm{~s}$ ). For control experiments (sham exposure), PS flow was turned on for $10 \mathrm{~s}$ in the same manner, but no electric pulses were delivered.

All experiments were performed at a room temperature of $22-24{ }^{\circ} \mathrm{C}$. Cell images were quantified with MetaMorph v. 7.5 (MDS).

\section{NsPEF exposure of selected individual cells on cover slips, field mapping and dosimetry}

The exposure procedures were similar to those described recently $[5,9,27]$. Electric pulses were delivered to a selected cell (or a group cells) with a pair of tungsten rod electrodes (0.08-mm diameter, $0.15 \mathrm{~mm}$ gap). With a help of a robotic micromanipulator (MP-225, Sutter, Novato, CA), these electrodes were positioned precisely at $50 \mu \mathrm{m}$ above the coverslip surface so that the selected cells were in the middle of the gap between their tips. Nearly rectangular 300-ns pulses were generated in a transmission line-type circuit, by closing a MOSFET switch upon a timed delivery of a TTL trigger pulse from pClamp software (MDS) via a Digidata 1322A output. The exact pulse delivery protocol and synchronization with image acquisition were programmed in pClamp. For sham exposures, all procedures were identical, but no pulses were triggered from pClamp. Sham exposures and different nsPEF treatments were alternated in a random manner.

The E-field between the electrodes was determined by 3D simulations with a finite element Maxwell equations solver Amaze 3D (Field Precision, Albuquerque, NM). Exactpulse shapes and amplitudes were captured and measured with a Tektronix TDS 3052 oscilloscope.

\section{Results and Discussion \\ NsPEF increases DCF production in cell suspensions}

As a first step, we checked if the measuring procedure itself (measuring DCF fluorescence by the plate reader) might facilitate photooxidation of $\mathrm{H}_{2} \mathrm{DCF}$ into DCF. Identical samples of dye-loaded cells were placed into 12 wells of a 96-well plate to form 4 groups, which were subjected to a different number of exposures to the excitation light of the plate reader. Group 1 was scanned at the first timepoint ( $2 \mathrm{~min}$ ); groups 1 and 2 were scanned at $10 \mathrm{~min}$; groups 1, 2, and 3 at $30 \mathrm{~min}$; and all 4 groups at $60 \mathrm{~min}$ (Fig. 1). In all the groups, and in different cell lines, DCF emission gradually increased with time, reflecting gradual selfoxidation and/or cell metabolism-mediated oxidation of $\mathrm{H}_{2} \mathrm{DCF}$. The yield of DCF was the same in all 4 groups; therefore, repeated exposures to the excitation light of the plate reader did not cause photooxidation.

In Jurkat cells, exposure to $300-n s$ pulses at $4.5 \mathrm{kV} / \mathrm{cm}$ increased the formation of DCF in comparison to the parallel control samples (Fig. 2). Longer trains of electric pulses caused more profound effect, and the difference from the control gradually increased with time after the exposure. Apparently this process reflects gradual accumulation of cell damage following nsPEF exposure, which can include damage to mitochondria $[3,48]$ and oxidation of the dye by leaking ROS and cytochrome C [48]. 
Notably, among various cell lines tested for the ability to withstand nsPEF exposures, Jurkat cells were the most vulnerable [17, 49]. An nsPEF-resistant cell line U937 showed a different response (Fig. 3): DCF level increased immediately after the exposure, but later on the difference from the parallel control remained constant or even decreased.

It remains to be established whether the reduced response in U937 cells as compared to Jurkat was related to better survival or it was just coincidental. Notably, both cell lines displayed an immediate, dose-dependent post-exposure jump in $\mathrm{H}_{2} \mathrm{DCF}$ oxidation. The magnitude of this jump was approximately the same in Jurkat and U937 cells, despite profound differences in cell physiology and survival. This jump could reflect formation of ROS directly by electrochemical rather than biological processes.

Indeed, although increasing the cell density enhanced the response to nsPEF, this enhancement was weaker than expected (Fig. 4). For different exposure conditions, a 5-fold increase in the cell density resulted in just a 2 - or 3-fold increase in the DCF yield. This observation also suggested that at least some fraction of the dye was oxidized in a process that did not depend on the cell density, such as electrochemical oxidation in the extracellular medium.

In a separate series of experiments, we tested if oxidation is affected by the temperature at which cells are incubated after nsPEF exposure. If ROS were generated due to nsPEFtriggered cell degradation, such ROS production should be inhibited by cooling and facilitated by heating. U937 cells were exposed to nsPEF at room temperature $\left(24{ }^{\circ} \mathrm{C}\right)$ and immediately chilled down to $4{ }^{\circ} \mathrm{C}$, or heated to $37{ }^{\circ} \mathrm{C}$, or were left at $24{ }^{\circ} \mathrm{C} . \mathrm{H}_{2} \mathrm{DCF}$ oxidation was measured after a $30-\mathrm{min}$ incubation. Negative control samples were shamexposed (zero pulses), and positive controls were treated with TBHP.

These experiments established increased DCF levels in both nsPEF-exposed and control samples incubated at higher temperatures. However, for each tested temperature, the difference between exposed samples (100 or 200 pulses) and sham-exposed controls was the same (Fig. 5). In contrast, DCF production by TBHP was profoundly enhanced at higher temperatures. Thus, higher temperatures increased both baseline $\mathrm{H}_{2} \mathrm{DCF}$ oxidation (either by cell metabolism or due to self-oxidation of the dye) and chemically induced oxidation.

NsPEF exposure of U937 cells samples caused oxidation at the time of exposure, but not as a result of post-exposure biochemical processes or cell degradation (this result is also consistent with data in Fig. 3).

\section{NsPEF causes $\mathrm{H}_{2}$ DCF oxidation in cell-free media}

The above observations suggested that nsPEF-induced $\mathrm{H}_{2} \mathrm{DCF}$ oxidation is not necessarily dependent on the presence of cells and may result from electrochemical processes in cellfree-media.

$\mathrm{H}_{2}$ DCFDA was converted into $\mathrm{H}_{2}$ DCF by alkaline deacetylation (as described above in Methods) and added to RPMI growth medium without serum and without phenol red. This medium was exposed to 50,100 , or $200300-\mathrm{ns}$ pulses at 4.9 or $9.8 \mathrm{kV} / \mathrm{cm}, 1$ or $0.3 \mathrm{~Hz}$. Indeed, all these treatments significantly increased DCF yield compared to sham exposure (Fig. 6A); the effect increased for the larger number of pulses. Importantly, the DCF yield increased without any measurable heating of the sample by nsPEF (Fig. 6B). Higher DCF production at $0.3 \mathrm{~Hz}$ compared to $1 \mathrm{~Hz}$ also pointed to the non-thermal nature of the effect. Higher DCF yield for longer exposures suggested the presence of long-lived electrochemical species that facilitated oxidation of the dye during the time intervals between the pulses. However, the impact of self-oxidation of the dye with time could not be excluded. 
A similar increase in DCF production was observed when a simple salt buffer (PS) was used instead of the RPMI medium (Fig. 7). Exposure to 400 pulses (300 ns, $1 \mathrm{~Hz}$ ) at 0.9, 1.8, or $3.6 \mathrm{kV} / \mathrm{cm}$, respectively, increased $\mathrm{H}_{2}$ DCF oxidation 2-fold ( $\mathrm{p}<0.05$ ), 5 -fold ( $\mathrm{p}<0.01$ ), and 10 -fold ( $\mathrm{p}<0.01$ ). In order to identify specific ROS type(s) generated by nsPEF, different ROS scavengers were added to the buffer before nsPEF exposure. For exposures at $3.6 \mathrm{kV} /$ $\mathrm{cm}, \mathrm{CAT}$ and CAT-SOD cocktail decreased $\mathrm{H}_{2} \mathrm{DCF}$ oxidation about twofold $(\mathrm{p}<0.01$ ); the effect of mannitol was not significant. The data indicated that nsPEF within the studied range did not produce a significant amount of hydroxyl radicals and pointed to the generation of hydrogen peroxide by nsPEF exposure (at least at $3.6 \mathrm{kV} / \mathrm{cm}$ ). However, the formation of other reactive species could not be excluded.

\section{Detection of nsPEF-generated $\mathrm{H}_{\mathbf{2}} \mathrm{O}_{\mathbf{2}}$ using Amplex Red assay}

Although the protective effect of CAT and CAT-SOD cocktail was successfully replicated in two additional, independent series of experiments (data not shown), it was not unambiguous. CAT is known to interfere with $\mathrm{H}_{2} \mathrm{DCF}$ oxidation [43], and we consistently observed that the presence of CAT increased DCF formation in parallel control samples. The same process could take place in the exposed samples, and it was difficult or impossible to isolate it from the protective effect of CAT. Therefore, we decided to verify hydrogen peroxide production by nsPEF in an assay with Amplex Red reagent. This assay is specifically sensitive to $\mathrm{H}_{2} \mathrm{O}_{2}$, which, in the presence of HRP, oxidizes Amplex Red into resorufin [46].

Using the Amplex Red assay, the yield of resorufin was linear for $\mathrm{H}_{2} \mathrm{O}_{2}$ concentrations of up to $20 \mu \mathrm{M}$ (calibration data not shown). Exposure of PBS-based Amplex Red working solution to 3,000 pulses ( $300 \mathrm{~ns}, 30 \mathrm{~Hz}, 1.8$ or $4.5 \mathrm{kV} / \mathrm{cm}$ ) caused the formation of $0.6-1.2$ $\mu \mathrm{M}$ of $\mathrm{H}_{2} \mathrm{O}_{2}$ (Fig. 8). Although the yield of $\mathrm{H}_{2} \mathrm{O}_{2}$ was not high, it could potentially contribute to stimulatory and cytotoxic effects of nsPEF.

\section{Cytotoxicity of $\mathrm{H}_{2} \mathrm{O}_{2}$ in Jurkat cells}

In order to estimate the potential role of electrochemically-generated $\mathrm{H}_{2} \mathrm{O}_{2}$ in the cytotoxic effect of nsPEF, we measured the effect of different $\mathrm{H}_{2} \mathrm{O}_{2}$ concentrations on cell survival. Jurkat cells were incubated for 3 hours at $37^{\circ} \mathrm{C}$ in serum-free RPMI medium in the presence of different concentrations of $\mathrm{H}_{2} \mathrm{O}_{2}$. Next, the samples were diluted with the complete growth medium with serum, collected by gentle centrifugation, resuspended in a fresh complete growth medium, and placed in the incubator. Cell survival was assessed at 4 and $24 \mathrm{hr}$ after the onset of incubation with $\mathrm{H}_{2} \mathrm{O}_{2}$.

Jurkat cells showed predominantly delayed cell death following exposure to low concentrations of $\mathrm{H}_{2} \mathrm{O}_{2}$ (Fig. 9). The threshold $\mathrm{H}_{2} \mathrm{O}_{2}$ concentration for inducing cell death was at or below $6 \mu \mathrm{M}$, which is consistent with findings in other cell lines [50].

Using 300-ns pulses at $2.25 \mathrm{kV} / \mathrm{cm}$, the $\mathrm{LD}_{50}$ for Jurkat cells was at $28 \mathrm{~J} / \mathrm{g}$, which corresponded to approximately 1,600 pulses [17]. The yield of $\mathrm{H}_{2} \mathrm{O}_{2}$ from such treatment would be under $1 \mu \mathrm{M}$, so the nsPEF-induced cell death was caused primarily by other mechanisms than $\mathrm{H}_{2} \mathrm{O}_{2}$ formation. At the same time, $\mathrm{H}_{2} \mathrm{O}_{2}$ is not necessarily the only ROS formed by nsPEF, and biochemically-generated ROS could potentially add to the effect of electrochemically-induced ROS (e.g., see Fig. 2 and 3). Furthermore, ROS can be more damaging in cells already injured by electroporation than in healthy cells with properly functioning antioxidant defense. The question whether ROS scavengers may assist survival of nsPEF-treated cells is currently being explored, and findings will be reported in a separate publication. 


\section{Detection of oxidative response in individual nsPEF-exposed cells by confocal fluorescence microscopy}

In the microscope-based nsPEF exposure setup, the electric field was created in a limited space between two electrodes inserted into the bath. In contrast to cuvette exposures where the entire volume of cell suspension was exposed to nearly uniform electric field, in the microscope setup nsPEF was delivered into about $0.01 \%$ of the entire bath volume. As a result, any ROS produced extracellularly by nsPEF are likely to be quickly diluted in the large volume of the unexposed buffer. Therefore, microscope experiments were specifically focused on detecting intracellular ROS.

Even after tuning the excitation laser intensity to minimum, time lapse imaging of cells loaded with $\mathrm{H}_{2} \mathrm{DCF}$ caused profound photooxidation of the dye. The emission of dye-loaded Jurkat cells increased gradually and almost linearly, by about $5 \%$ per scan. Unexpectedly, exposure to 10 and, in particular, to 100 pulses $(300 \mathrm{~ns}, 12.8 \mathrm{kV} / \mathrm{cm}, 5 \mathrm{~Hz})$ slowed down or halted this gradual gain in fluorescence (Fig. 10, A). Apparently, electroporated cells were leaking the dye into the extracellular space, making it impossible to judge if nsPEF caused any intracellular oxidation in such exposure setting. Similar effects were observed in Jurkat and U937 cells loaded with Carboxy- $\mathrm{H}_{2} \mathrm{DCF}$, a dye which is supposed to be better retained in cells (data not shown).

When $\mathrm{H}_{2} \mathrm{DCF}$ was driven to complete photoactivation prior to the onset of the experiment, nsPEF exposure abruptly decreased the emission signal (Fig. 10, B), thereby providing further evidence for dye leakage from electropermeabilized cells. Although these experiments did not reach the intended goal, they provided an important insight on what was actually detected in cell suspension studies with $\mathrm{H}_{2}$ DCF dye (Figs. 2 and 3). In these experiments, cells were loaded with the dye, but there was no dye in the medium. Similarly to what was seen under the microscope, nsPEF exposure of cell suspensions caused dye leakage out of cells and its oxidation in the extracellular medium. The difference between dye oxidation in Jurkat and U937 cell suspensions (Fig. 3) could, to a certain extent, be explained by different extent of membrane damage and different dye leakage. Thus, it became unclear if the cells were actively involved in ROS generation after nsPEF exposure, or just served as a "vehicle" to deliver the dye that was oxidized extracellularly.

To answer this question, we performed experiments with a different dye (DHE). Although the impact of extracellularly-generated ROS on intracellular oxidation in the microscopebased exposure setup was already unlikely, we utilized even more stringent protocol by quickly and continually washing the "exposed" extracellular medium away from the cells (see Methods for details). These experiments required strong cell adhesion to the substrate and therefore were carried out in $\mathrm{CHO}$ cells.

Upon oxidation, DHE forms ethidium, which binds to nucleic acids and therefore is trapped even in electroporated cells. Bound ethidium is easily detected by bright fluorescence (Fig. 11, inset). NsPEF exposures (10, 20, or 40 pulses, $300 \mathrm{~ns}, 5 \mathrm{~Hz}, 11 \mathrm{kV} / \mathrm{cm}$ ) unequivocally increased DHE oxidation, whereas sham exposures (turning the solution flow on and off without nsPEF) had only minor effect. A representative experiment (out of eight) is shown in Fig. 11. Notably, oxidation of DHE continued for minutes after exposure.

These observations of intracellular DHE oxidation prove that nsPEF can initiate ROS production inside the cells and are consistent with recent reports that nsPEF may damage cell mitochondria $[3,20]$. 


\section{Summary}

Our study demonstrated that permeabilization of biomembranes is not the only mechanism how nsPEF can affect living cells. For the first time, we found that nsPEF triggers oxidation both extracellularly (in a process that does not require the presence of cells) and intracellularly, in a biologically-mediated pathway.

Although oxidation does not appear to be the lead mechanism of nsPEF interaction with biological cells and systems, it can contribute to cell damage and trigger specific responses. Oxidatively damaged areas of the cell membrane were found to be specifically sensitive to electroporation [51]. Such phenomena as nsPEF-induced cell swelling, blebbing, and increased non-selective transmembrane cation conductance may be in part mediated by oxidative effects. Along with membrane permeabilization, the antioxidant defense and ROS formation may be among the factors that determine the cytotoxic effect and the efficiency of tumor and tissue ablation by nsPEF.

\section{Acknowledgments}

The study was supported by R01CA125482 from the National Cancer Institute and R01GM088303 from the National Institute of General Medical Sciences (AGP), and MIP-131/2010 from the Research Council of Lithuania (GS). RRR was supported by the European Union Structural Funds project "Postdoctoral Fellowship Implementation in Lithuania."

\section{Abbreviations}

$\begin{array}{ll}\text { CAT } & \text { catalase } \\ \text { DCF } & 2^{\prime}, 7^{\prime} \text {-dichlorofluorescein } \\ \text { DHE } & \text { dihidroethidium } \\ \text { DIC } & \text { differential-interference contrast } \\ \text { DMSO } & \text { dimethylsulfoxide } \\ \text { EP } & \text { electric pulses } \\ \text { FBS } & \text { fetal bovine serum } \\ \text { H2DCFDA } & \text { dichlorodihydrofluorescein diacetate } \\ \text { H2DCF } & \text { dichlorodihydrofluorescein } \\ \text { HRP } & \text { horseradish peroxidase } \\ \text { IRE } & \text { irreversible electroporation } \\ \text { NSCC } & \text { nonselective cation channels } \\ \text { nsPEF } & \text { nanosecond pulsed electric field } \\ \text { PBS } & \text { phosphate-buffered saline } \\ \text { PS } & \text { physiological solution } \\ \text { ROS } & \text { reactive oxygen species } \\ \text { SOD } & \text { superoxide dismutase } \\ \text { TBHP } & \text { tert-butyl hydroperoxide }\end{array}$




\section{References}

1. Schoenbach KH, Beebe SJ, Buescher ES. Bioelectromagnetics. 2001; 22:440-448. [PubMed: 11536285]

2. Schoenbach KH, Katsuki S, Stark RH, Buesher ES, Beebe SJ. IEEE Trans Plasma Sci. 2002; 30:293-300.

3. Napotnik TB, Wu YH, Gundersen MA, Miklavcic D, Vernier PT. Bioelectromagnetics. 2012; 33:257-264. [PubMed: 21953203]

4. White JA, Blackmore PF, Schoenbach KH, Beebe SJ. J Biol Chem. 2004; 279:22964-22972. [PubMed: 15026420]

5. Pakhomov AG, Bowman AM, Ibey BL, Andre FM, Pakhomova ON, Schoenbach KH. Biochem Biophys Res Commun. 2009; 385:181-186. [PubMed: 19450553]

6. Pakhomov AG, Shevin R, White JA, Kolb JF, Pakhomova ON, Joshi RP, Schoenbach KH. Arch Biochem Biophys. 2007; 465:109-118. [PubMed: 17555703]

7. Vernier PT, Sun Y, Gundersen MA. BMC Cell Biol. 2006; 7:37. [PubMed: 17052354]

8. Pakhomov, AG.; Pakhomova, ON. Advanced Electroporation Techniques in Biology in Medicine. Pakhomov, AG.; Miklavcic, D.; Markov, MS., editors. CRC Press; Boca Raton: 2010. p. 178-194.

9. Bowman AM, Nesin OM, Pakhomova ON, Pakhomov AG. J Membr Biol. 2010; 236:15-26. [PubMed: 20623351]

10. Nesin OM, Pakhomova ON, Xiao S, Pakhomov AG. Biochim Biophys Acta. 2011; 1808:792-801. [PubMed: 21182825]

11. Napotnik TB, Rebersek M, Kotnik T, Lebrasseur E, Cabodevila G, Miklavcic D. Med Biol Eng Comput. 2010; 48:407-413. [PubMed: 20361267]

12. Gowrishankar TR, Weaver JC. Biochem Biophys Res Commun. 2006; 349:643-653. [PubMed: 16959217]

13. Smith KC, Weaver JC. Biophys J. 2008; 95:1547-1563. [PubMed: 18408042]

14. Craviso GL, Choe S, Chatterjee I, Vernier PT. Bioelectrochemistry. 2011

15. Craviso GL, Choe S, Chatterjee P, Chatterjee I, Vernier PT. Cell Mol Neurobiol. 2010; 30:12591265. [PubMed: 21080060]

16. Wang S, Chen J, Chen MT, Vernier PT, Gundersen MA, Valderrabano M. Biophysical journal. 2009; 96:1640-1648. [PubMed: 19217879]

17. Ibey BL, Pakhomov AG, Gregory BW, Khorokhorina VA, Roth CC, Rassokhin MA, Bernhard JA, Wilmink GJ, Pakhomova ON. Biochim Biophys Acta. 2010; 1800:1210-1219. [PubMed: 20691249]

18. Pakhomov AG, Phinney A, Ashmore J, Walker K, Kono KJS, Schoenbach KS, Murphy MR. IEEE Transactions on Plasma Science. 2004; 32:1579-1585.

19. Ren W, Beebe SJ. Apoptosis. 2011; 16:382-393. [PubMed: 21213047]

20. Ren W, Sain NM, Beebe SJ. Biochemical and biophysical research communications. 2012; 421:808-812. [PubMed: 22554515]

21. Yang W, Wu YH, Yin D, Koeffler HP, Sawcer DE, Vernier PT, Gundersen MA. Technol Cancer Res Treat. 2011; 10:281-286. [PubMed: 21517135]

22. Nuccitelli R, Chen X, Pakhomov AG, Baldwin WH, Sheikh S, Pomicter JL, Ren W, Osgood C, Swanson RJ, Kolb JF, Beebe SJ, Schoenbach KH. Int J Cancer. 2009; 125:438-445. [PubMed: 19408306]

23. Nuccitelli R, Tran K, Sheikh S, Athos B, Kreis M, Nuccitelli P. International Journal of Cancer. 2010; 127:1727-1736.

24. Chen X, Zhuang J, Kolb JF, Schoenbach KH, Beebe SJ. Technology in cancer research \& treatment. 2012; 11:83-93. [PubMed: 22181334]

25. Breton M, Mir LM. Bioelectromagnetics. 2012; 33:106-123.

26. Nesin V, Bowman AM, Xiao S, Pakhomov AG. Bioelectromagnetics. 2012; 33:394-404. [PubMed: 22213081]

27. Pakhomova ON, Gregory BW, Khorokhorina VA, Bowman AM, Xiao S, Pakhomov AG. PLoS One. 2011; 6:e17100. [PubMed: 21347394] 
28. Zimmermann U, Friedrich U, Mussauer H, Gessner P, Hämel K, Sukhorukov V. IEEE Transactions on Plasma Science. 2000; 28:72-82.

29. Muller KJ, Sukhorukov VL, Zimmermann U. J Membrane Biol. 2001; 184:161-170. [PubMed: 11719852]

30. Lin, JC., editor. Microwave auditory effects and applications. Charles C. Thomas; Springfield: 1978.

31. Chou CK, Guy AW, Galambos R. J Acoust Soc Am. 1982; 71:1321-1334.

32. Chen W. Bioelectrochemistry. 2004; 62:47-56. [PubMed: 14990325]

33. Chen W. Ann N Y Acad Sci. 2005; 1066:92-105. [PubMed: 16533921]

34. Walker K 3rd, Pakhomova ON, Kolb J, Schoenbach KS, Stuck BE, Murphy MR, Pakhomov AG. Bioelectromagnetics. 2006; 27:221-225. [PubMed: 16342277]

35. Ward JF. Prog Nucleic Acid Res Mol Biol. 1988; 35:95-125. [PubMed: 3065826]

36. Barros LF, Hermosilla T, Castro J. Comp Biochem Physiol A Mol Integr Physiol. 2001; 130:401409. [PubMed: 11913453]

37. Barros LF, Stutzin A, Calixto A, Catalan M, Castro J, Hetz C, Hermosilla T. Hepatology. 2001; 33:114-122. [PubMed: 11124827]

38. Stacey M, Stickley J, Fox P, Statler V, Schoenbach K, Beebe SJ, Buescher S. Mutat Res. 2003; 542:65-75. [PubMed: 14644355]

39. Gabriel B, Teissie J. European Journal of Biochemistry. 1994; 223:25-33. [PubMed: 8033899]

40. Bonnafous P, Vernhes M, Teissie J, Gabriel B. Biochim Biophys Acta. 1999; 1461:123-134. [PubMed: 10556494]

41. Sabri N, Pelissier B, Teissie J. European Journal of Biochemistry. 1996; 238:737-743. [PubMed: 8706675]

42. Lecour S, Baouali AB, Maupoil V, Chahine R, Abadie C, Javouhey-Donzel A, Rochette L, Nadeau R. Free Radic Biol Med. 1998; 24:573-579. [PubMed: 9559869]

43. Chen X, Zhong Z, Xu Z, Chen L, Wang Y. Free Radic Res. 2010; 44:587-604. [PubMed: 20370560]

44. Rota C, Chignell CF, Mason RP. Free Radic Biol Med. 1999; 27:873-881. [PubMed: 10515592]

45. Korystov YN, Shaposhnikova VV, Korystova AF, Emel'yanov MO. Radiat Res. 2007; 168:226232. [PubMed: 17638409]

46. Gomes A, Fernandes E, Lima JLFC. J Biochem Bioph Meth. 2005; 65:45-80.

47. Richardson, A.; Fedorof, S. Protocols for Neural Cell Culture. Richardson, A.; Fedorof, S., editors. Humana Press; Totowa, NJ: 2001. p. 333-339.

48. Beebe SJ, Fox PM, Rec LJ, Willis EL, Schoenbach KH. Faseb J. 2003; 17:1493-1495. [PubMed: 12824299]

49. Ibey BL, Roth CC, Pakhomov AG, Bernhard JA, Wilmink GJ, Pakhomova ON. PLoS One. 2011; 6:e15642. [PubMed: 21390200]

50. Hachiya M, Akashi M. Radiation Research. 2005; 163:271-282. [PubMed: 15733034]

51. Vernier PT, Levine ZA, Wu YH, Joubert V, Ziegler MJ, Mir LM, Tieleman DP. PLoS One. 2009; 4:e7966. [PubMed: 19956595] 
- Nanosecond electric pulses permeabilize cell membrane.

- We found that nanosecond electric pulses also cause ROS production.

- Exposure to nanosecond pulses increased ROS levels both in cells and in cellfree-media.

- ROS formation may lead to cell stimulation and/or oxidative cell damage. 


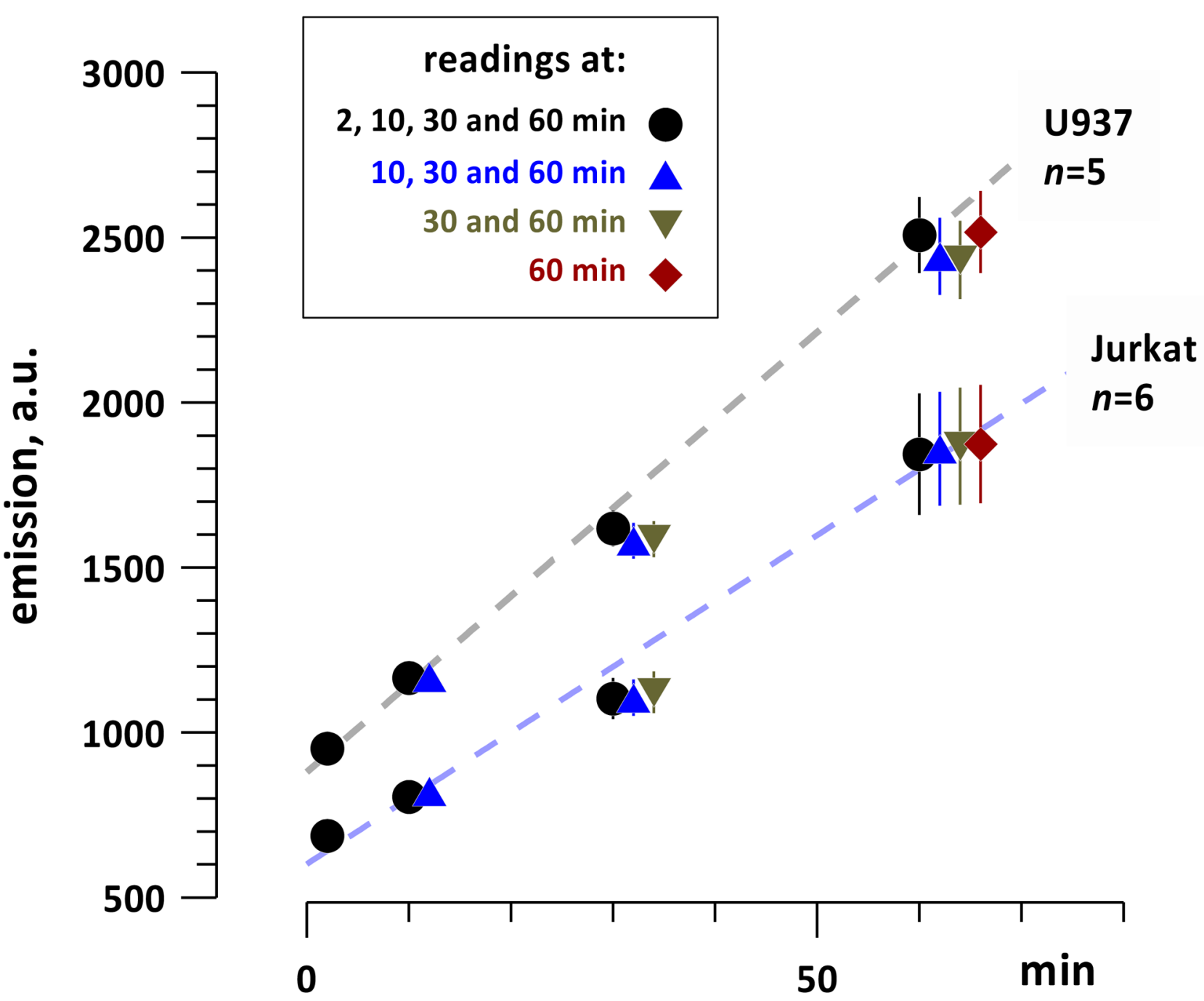

Fig. 1.

Time-dependent increase of $\mathrm{H}_{2} \mathrm{DCF}$ oxidation in dye-loaded U937 and Jurkat cells, and the lack of dye photoactivation by repeated measurements with the plate reader. Identical cell samples were loaded in different wells of a 96-well plate; DCF emission was measured once or several times during 1-hr incubation (mean $+/-$ s.e.). The stopwatch was started (0 min) when all cell samples were dispensed in the respective wells of a 96-well plate. Note gradual increase in DCF formation due to cell metabolism or self-oxidation of $\mathrm{H}_{2} \mathrm{DCF}$, whereas repeated measurements of the same well did not cause additional oxidation. See text for more detail. 


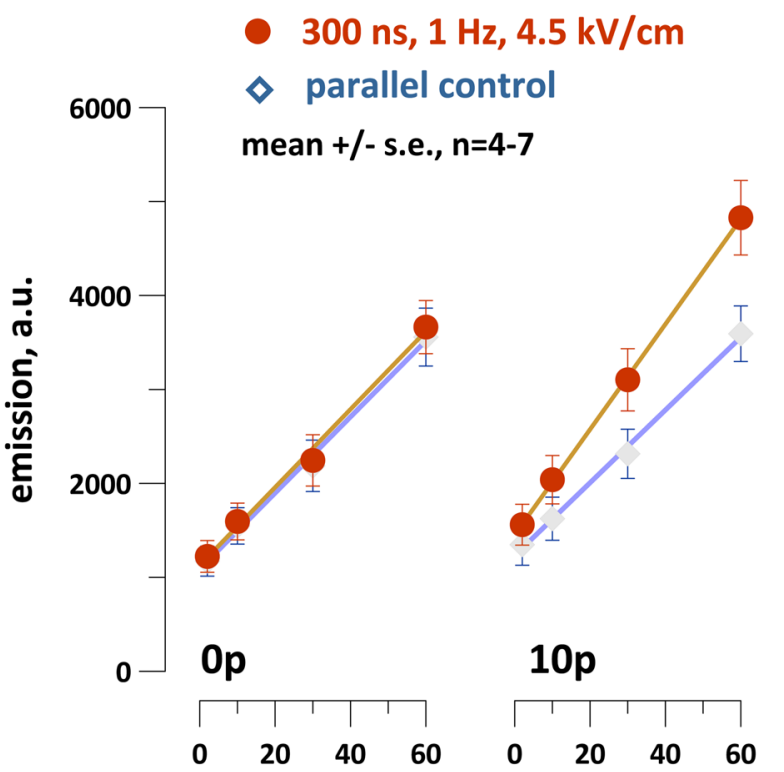

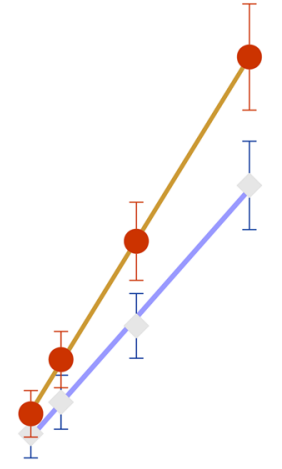
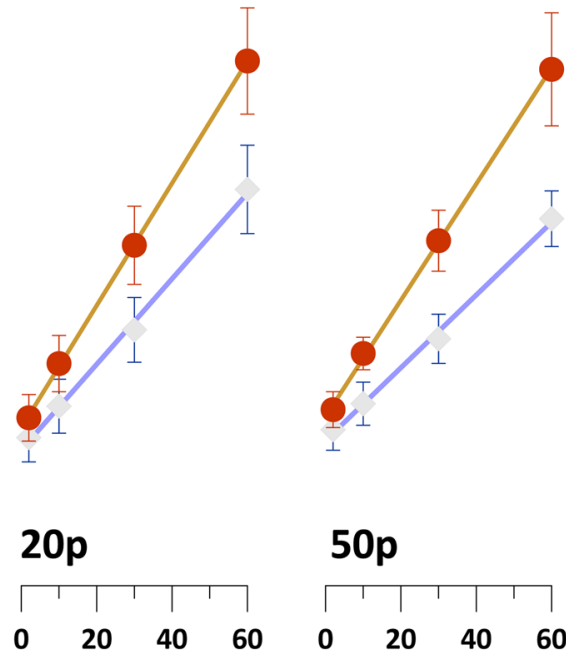

$100 p$

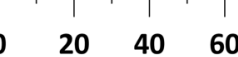

Fig. 2.

NsPEF exposure facilitates $\mathrm{H}_{2} \mathrm{DCF}$ oxidation in the suspension of dye-loaded Jurkat cells. The timepoint when exposure was completed is taken as zero; the number of pulses delivered to the sample (from 0 to 100) is indicated in the graphs. Immediately after the exposure, the samples were transferred into a 96 well plate, and DCF emission was measured repeatedly during the next hour. Between consecutive measurements the samples were incubated at $37^{\circ} \mathrm{C}$ with $5 \% \mathrm{CO}_{2}$ in air. Parallel control samples underwent all the same procedures (excluding nsPEF exposure) simultaneously with the exposed samples. 


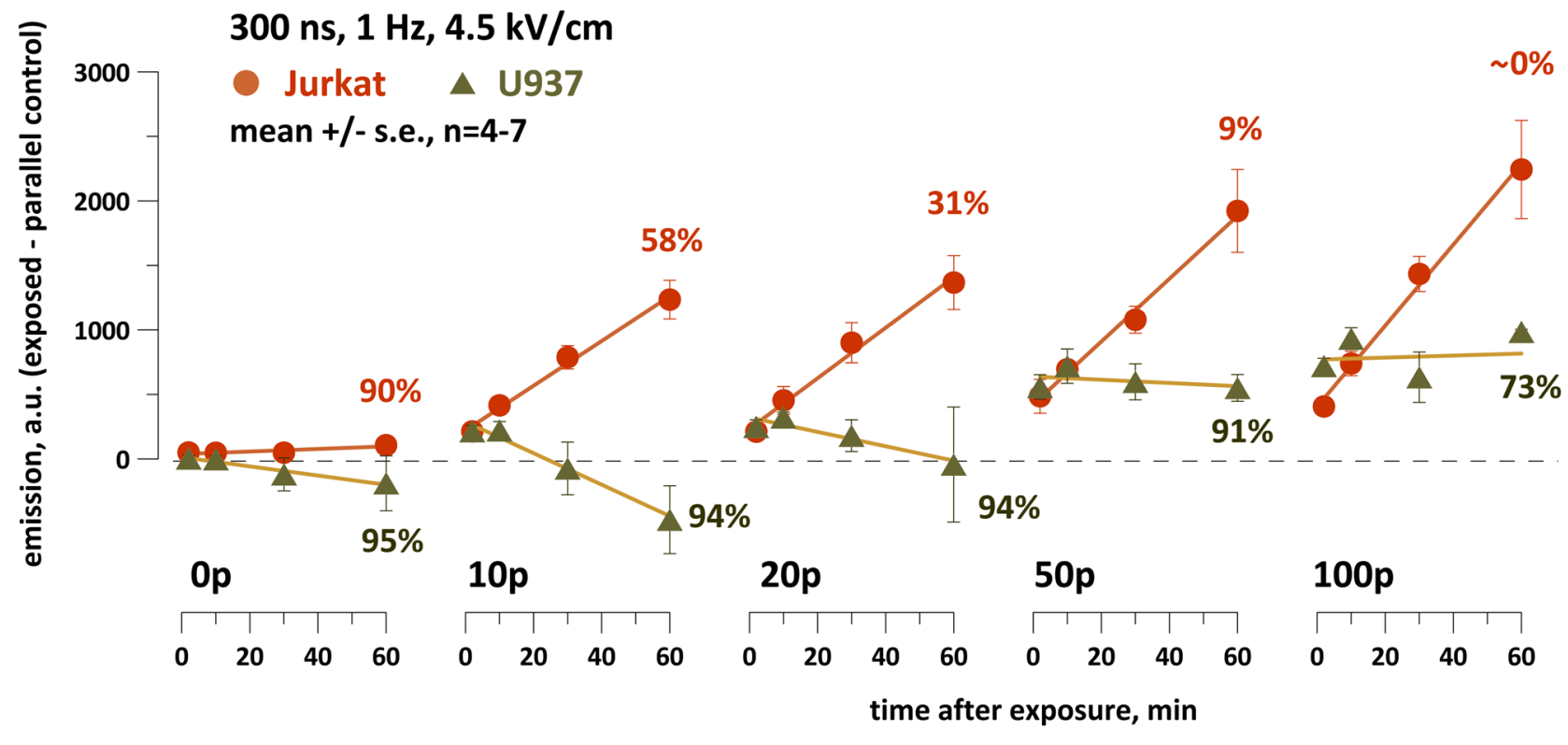

Fig. 3.

Different patterns of ROS formation in nsPEF-treated Jurkat and U937 cells. The vertical axis is the difference in DCF emission between the exposed sample and the time-matched parallel control. Numbers next to the plots indicate the percentage of viable cells as measured by trypan blue exclusion $60 \mathrm{~min}$ after $\mathrm{nsPEF}$ exposure $(\mathrm{n}=4$; s.e. is within $6 \%$ for all datapoints). See Fig. 2 and text for more detail. 


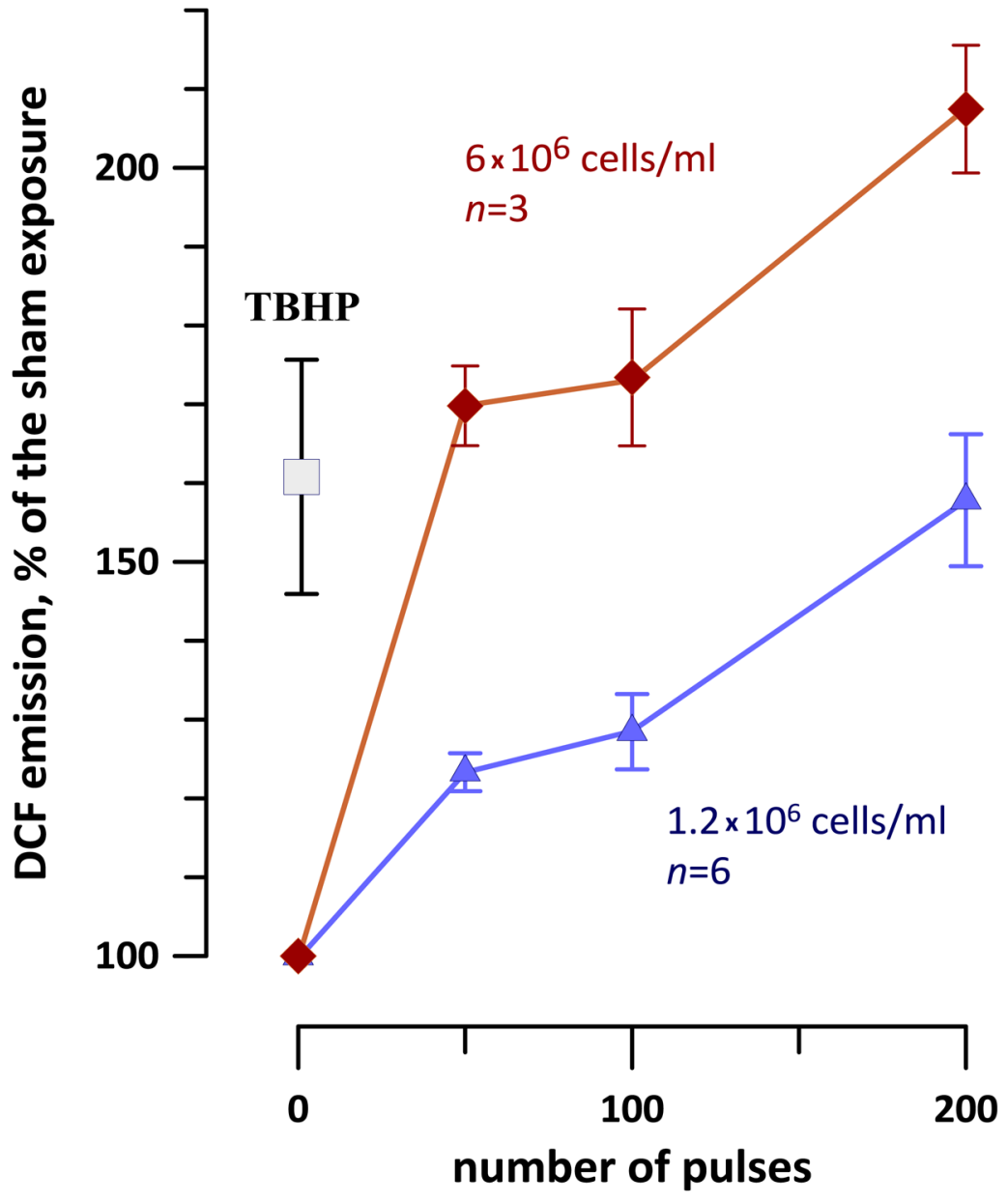

Fig. 4.

The effect of Jurkat cell density on $\mathrm{H}_{2}$ DCF oxidation by nsPEF $(0,50,100$, or 200300 -ns pulses at $4.5 \mathrm{kV} / \mathrm{cm}, 1 \mathrm{~Hz}$ ). Measurements were performed at about $10 \mathrm{~min}$ after the exposure and are presented as mean $+/-$ s.e. TBHP-treated samples $\left(1.2 \times 10^{6} \mathrm{cell} / \mathrm{ml}\right)$ were used as a positive control for ROS formation. 


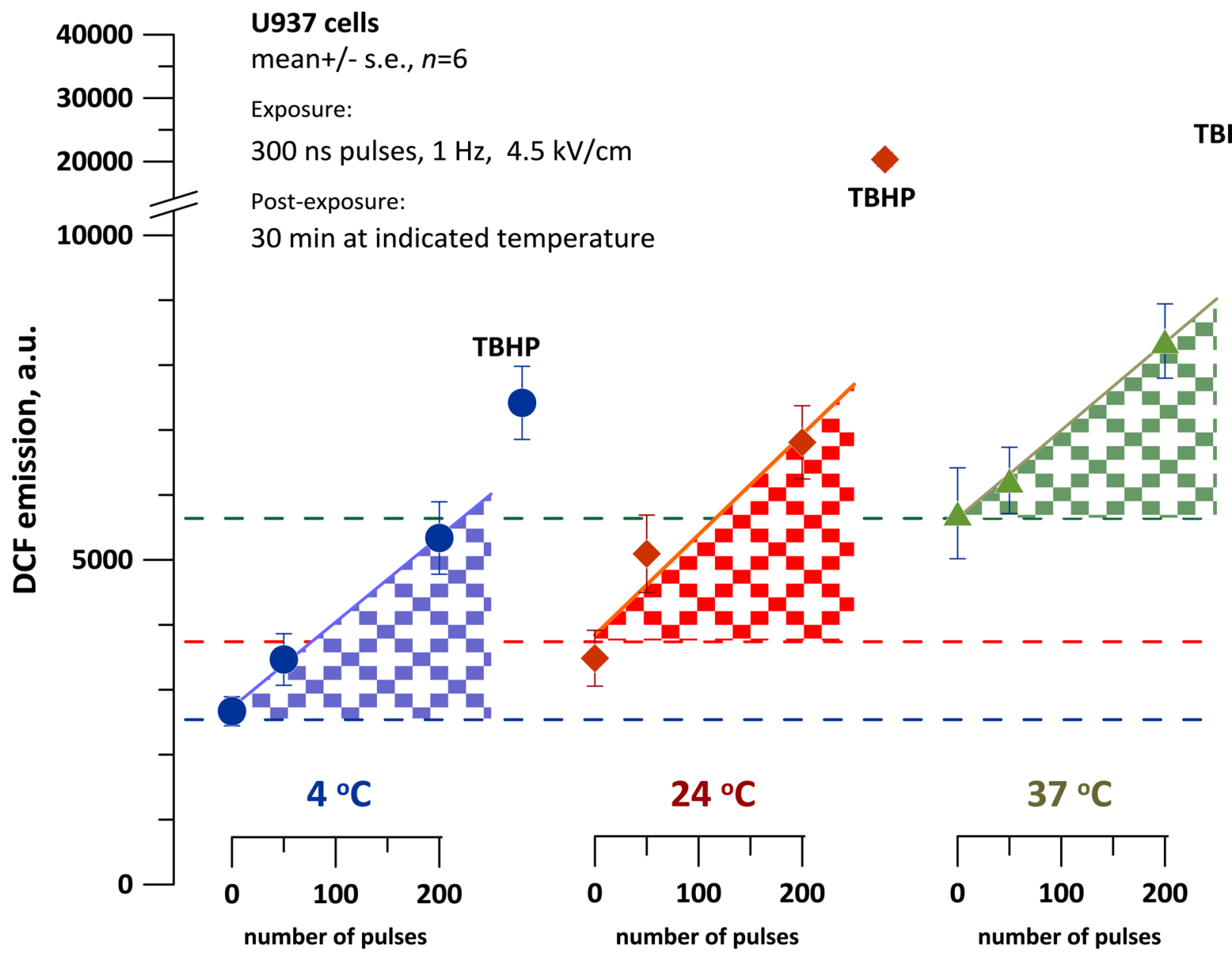

Fig. 5.

Effect of the incubation temperature on DCF formation in nsPEF-exposed U937 cells. Exposures at the indicated parameters were performed at the room temperature, followed by a 30-min incubation at 4,24 , or $37^{\circ} \mathrm{C}$. Same procedures were utilized for positive control samples (TBHP). DCF emission was measured immediately after the incubation. Note broken $\mathrm{Y}$-axis with a different scale after the break. For each temperature, shaded areas show DCF formation resulting from nsPEF exposure. See text for more detail. 

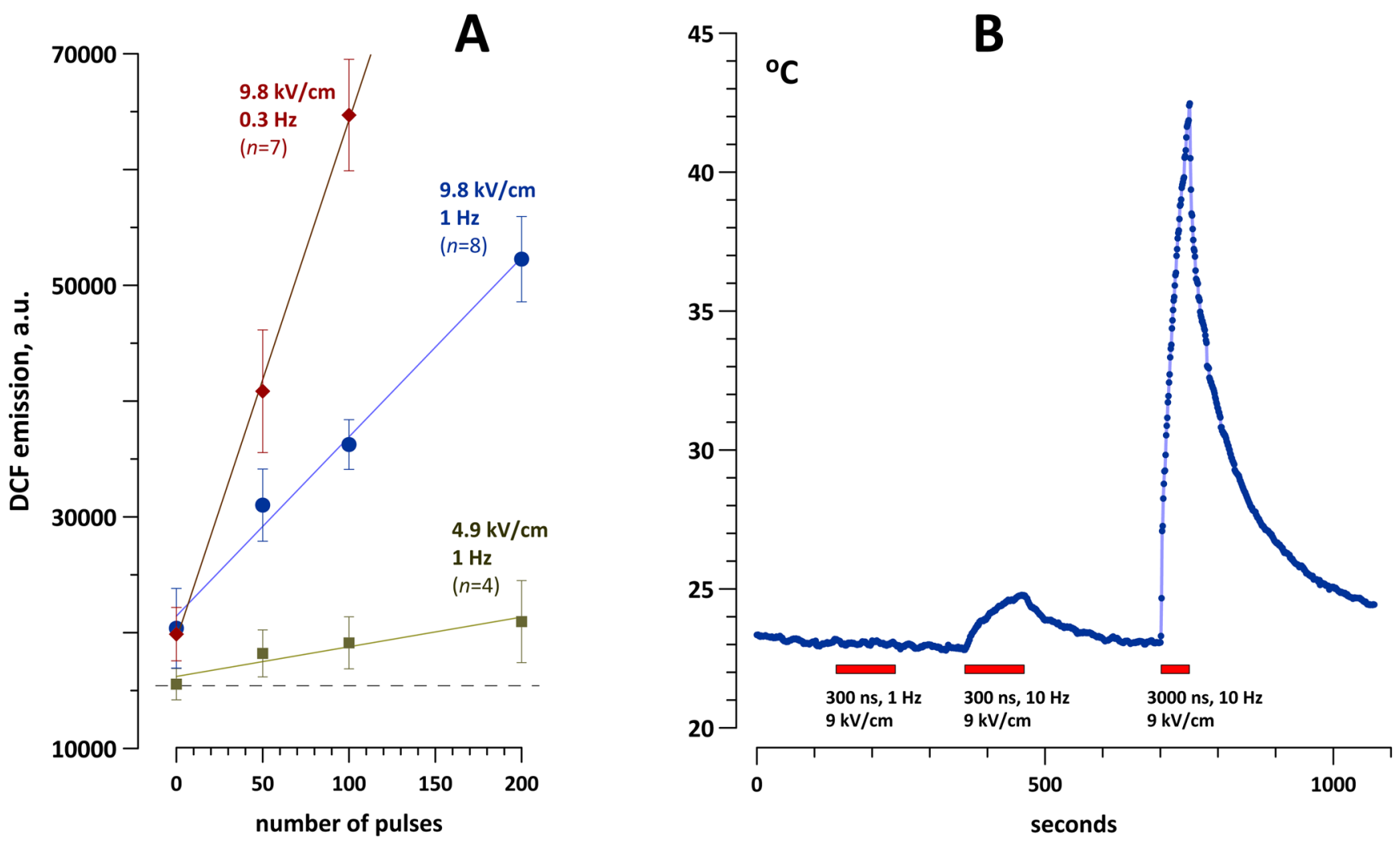

Fig. 6.

Nonthermal effect of $\mathrm{H}_{2}$ DCF oxidation by nsPEF in cell-free RPMI medium. The concentration of $\mathrm{H}_{2} \mathrm{DCF}$ was about $70 \mu \mathrm{M}$. A: Increased DCF formation (mean $+/-$ s.e.) as a result of nsPEF exposures using different numbers of pulses, pulse amplitudes, and repetition rates. B: Heating of the medium in a 1-mm gap electroporation cuvette by nsPEF trains (exposure time is shown by boxes). Note that all treatments shown in fragment $\mathbf{A}$ were below the intensity threshold for measurable heating. 


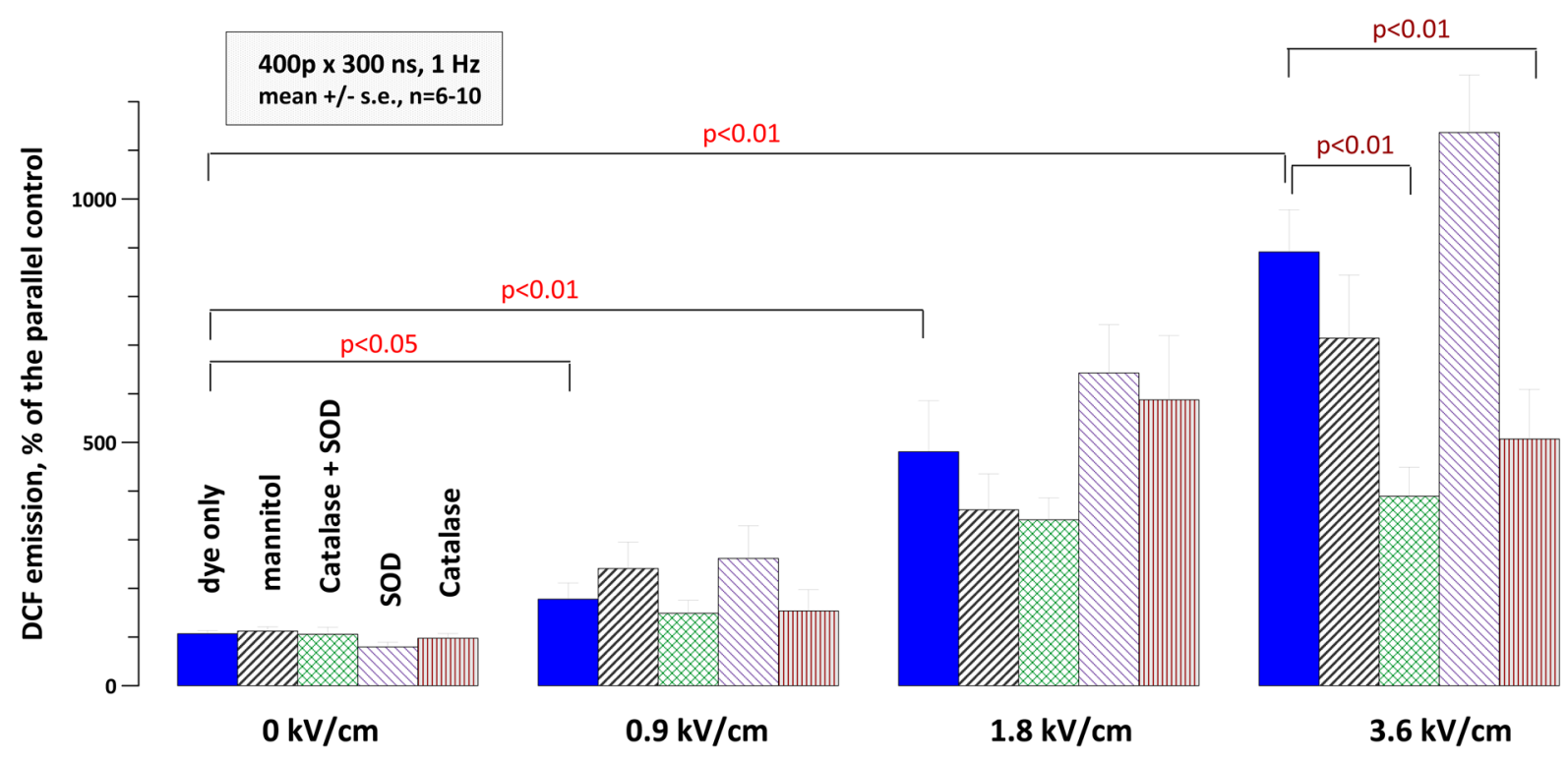

Fig. 7.

Effect nsPEF exposure and ROS scavengers on oxidation of $\mathrm{H}_{2} \mathrm{DCF}$ ( $20 \mu \mathrm{M}$ in PS). Note profound, dose dependent increase of DCF yield ( $p<0.05$ at $0.9 \mathrm{kV} / \mathrm{cm}$ and $\mathrm{p}<0.01$ at higher intensities; 1-tailed t-test with Dunnet's correction for multiple treated groups). The inhibition of $\mathrm{H}_{2} \mathrm{DCF}$ oxidation by tested scavengers was statistically significant for CAT and SOD+CAT at $3.6 \mathrm{kV} / \mathrm{cm}$, but not in any other groups. 


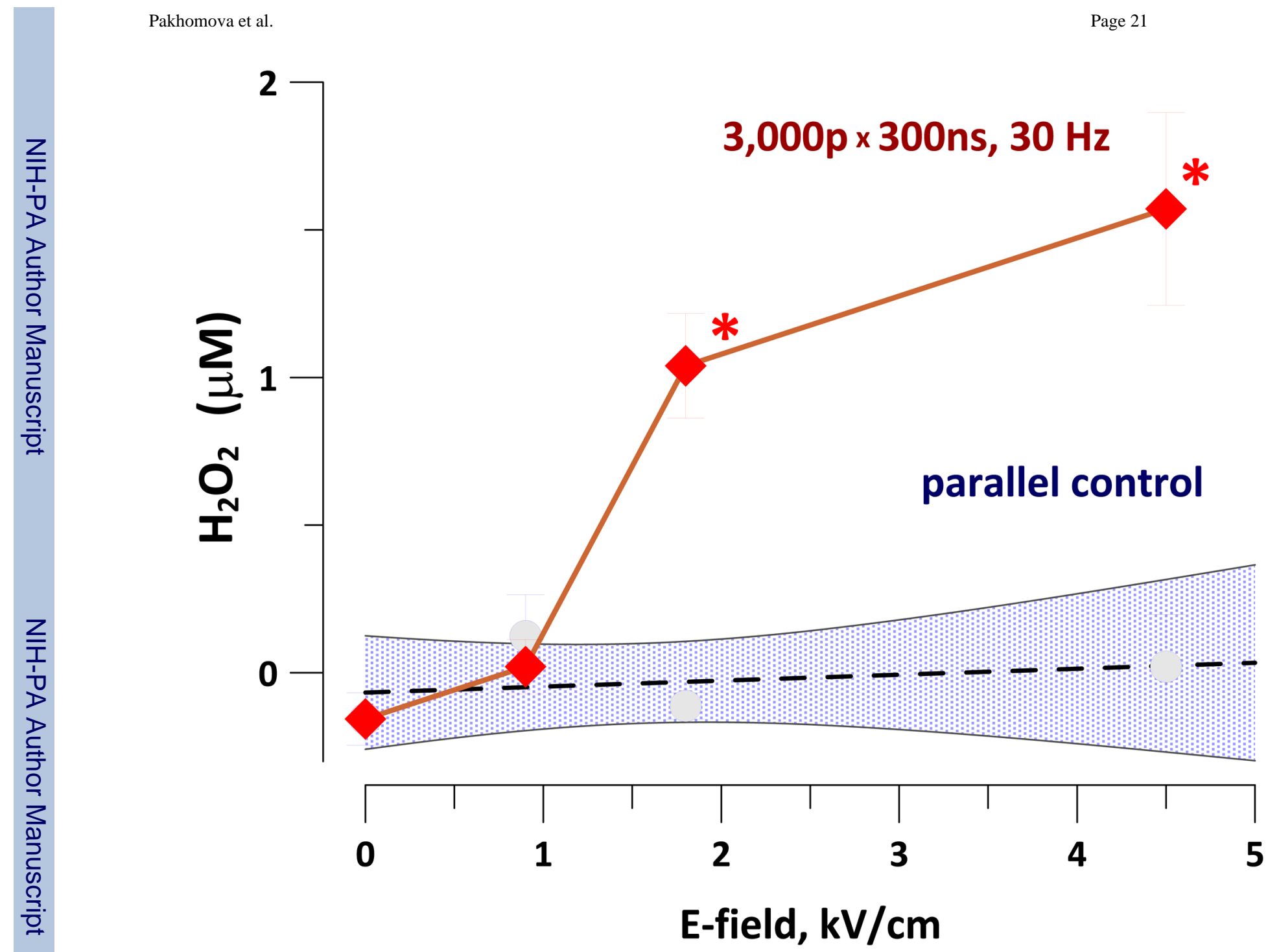

Fig. 8.

Yield of $\mathrm{H}_{2} \mathrm{O}_{2}$ in nsPEF-exposed PBS as measured with Amplex Red reagent (mean +/s.e., $\mathrm{n}=3$ ). Shaded area shows $95 \%$ confidence interval for control samples. * $\mathrm{p}<0.05$ compared to parallel control (two-tailed $t$ test). 


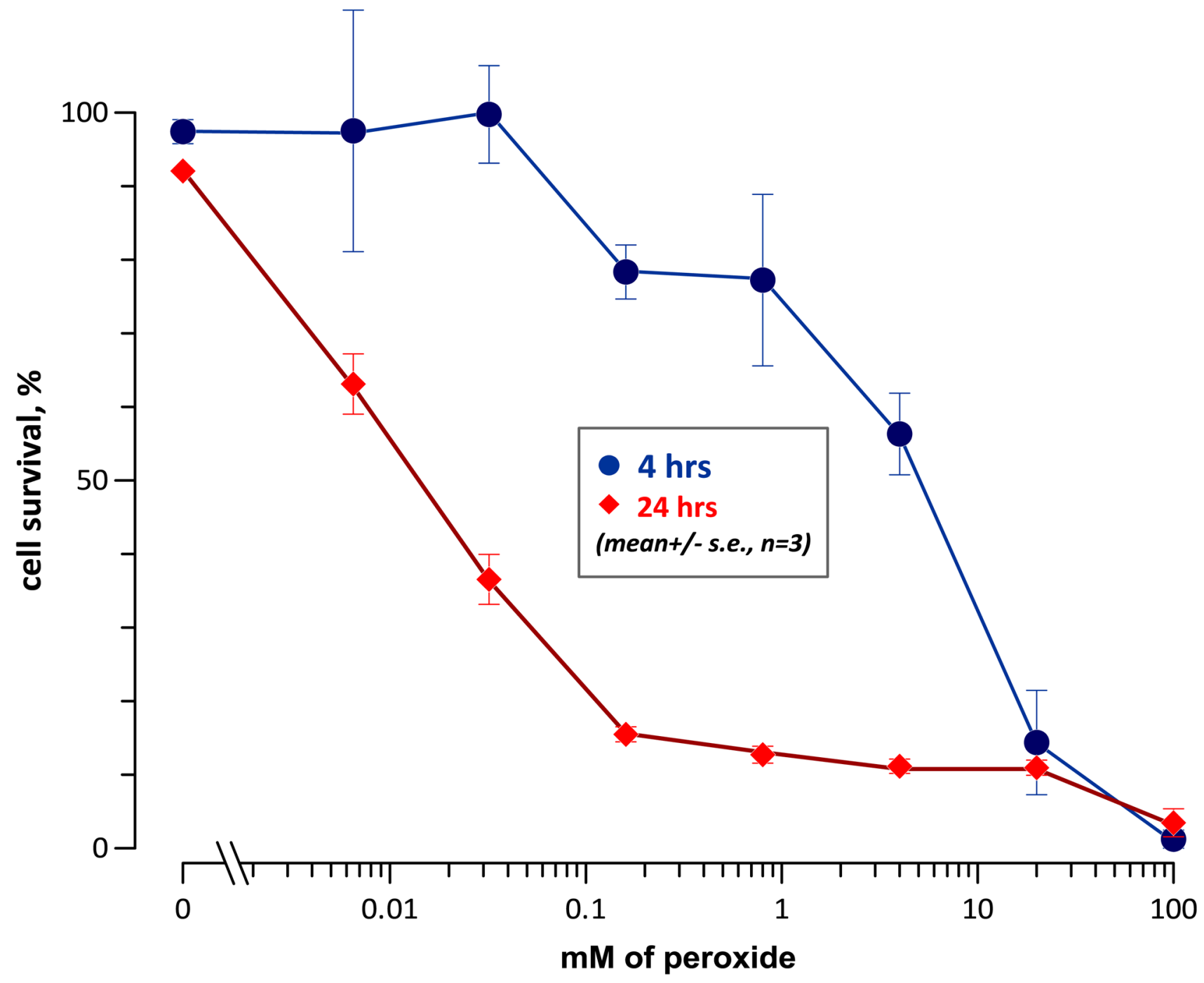

Fig. 9.

Effect of a 3-hr incubation with different concentrations of $\mathrm{H}_{2} \mathrm{O}_{2}$ on the survival of Jurkat cells. The fraction of live cells was measured using Cellometer (AO/PI assay) at 4 and $24 \mathrm{hr}$ after the start of the treatment. Cell survival was determined as a ratio of live cell fractions in $\mathrm{H}_{2} \mathrm{O}_{2}$-treated and control samples at the same time point. 

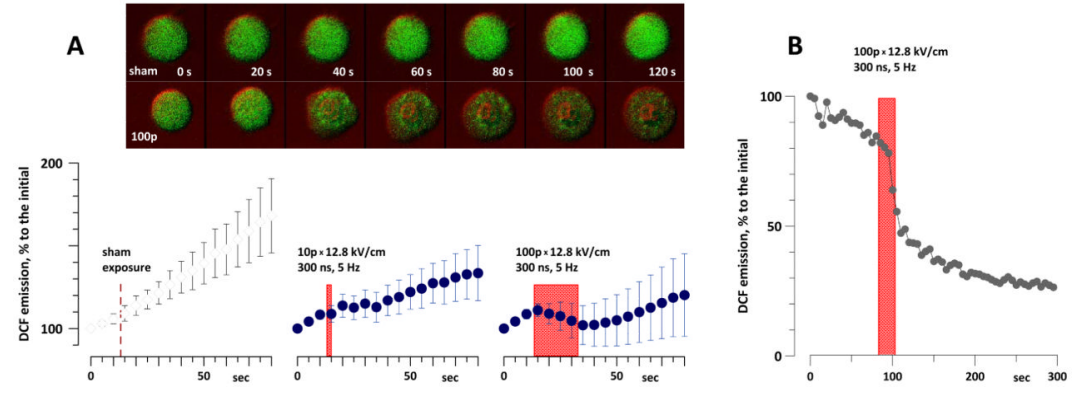

Fig. 10.

Suppression of the intracellular DCF emission by nsPEF. A: gradual fluorescence gain in Jurkat cells loaded with $\mathrm{H}_{2} \mathrm{DCF}$ is hampered by nsPEF (mean $+/-$ s.e., $n=6-8$ ). The dye emission gradually increased during time-lapse imaging due to photooxidation, despite the lowest setting of the excitation laser. The time interval of exposures is shown by boxes (by a vertical dashed line for sham exposure). The inset shows typical changes in cell fluorescence in a sham-exposed cell and after exposure to 100 pulses. Fluorescence images (green) were laid over DIC images (colored red for better contrast). B: same effect in an individual cell when the dye was driven to complete photoactivation prior to the onset of the experiment. Repeated imaging just caused photobleaching, and nsPEF abruptly decreased DCF emission. 


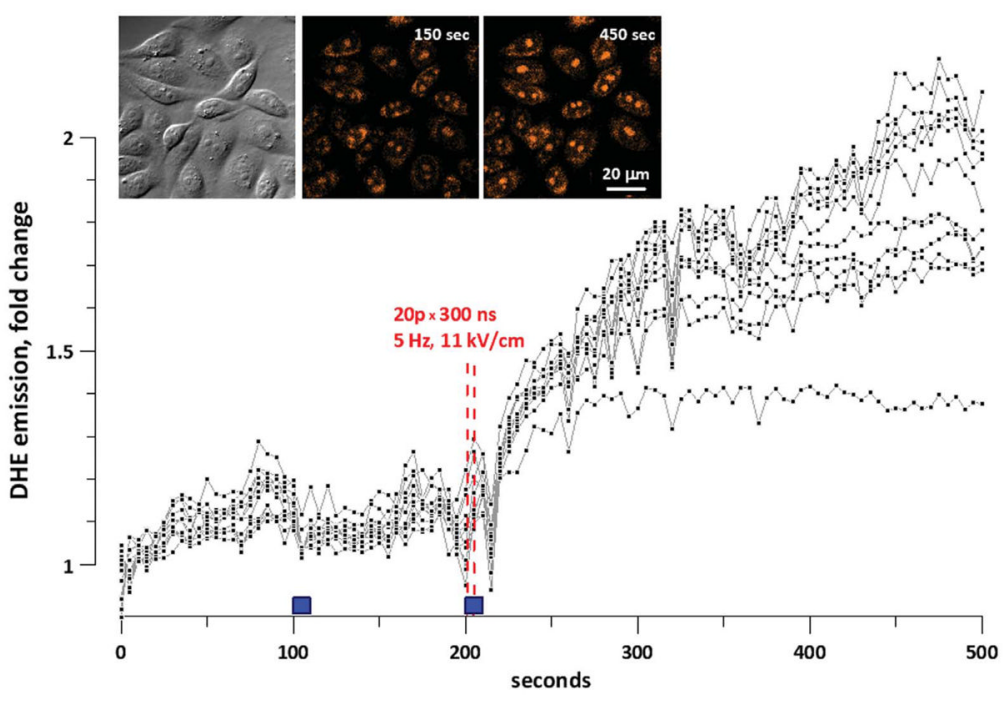

Fig. 11.

ROS formation in nsPEF-exposed CHO cells as evidenced by oxidation of dihidroethidium (DHE). The graph and insets show the data of one representative experiment (out of 8).

Cells were bathed in PS containing $30 \mu \mathrm{M}$ of DHE. A group of cells situated between nsPEF-delivering electrodes was imaged every $5 \mathrm{sec}$. Filled boxes above the abscissa show the time intervals when the solution flow in the bath was turned on. The first interval of perfusion was accompanied by a sham exposure (control). During the second interval of perfusion, cells were exposed to nsPEF (vertical dashed lines) Plots show DHE emission in each individual cell. Inset: DIC and fluorescence images of the cells at selected timepoints. 